\title{
Sexual dimorphism in development and venom production of the insular threatened pit viper Bothrops insularis (Serpentes: Viperidae) of Queimada Grande Island, Brazil
}

\author{
Silvia Regina Travaglia-Cardoso ${ }^{1}$, André Zelanis $^{2} \&$ Maria de Fátima Domingues Furtado ${ }^{3}$ \\ 1,3 Laboratório de Herpetologia, Instituto Butantan - SP, Av. Vital Brazil, 1500, 05503-900, São Paulo-SP, Brazil \\ ${ }^{2}$ Laboratório Especial de Toxinologia Aplicada (CAT/CEPID), Instituto Butantan-SP, Brazil \\ Email: ${ }^{1}$ silviacardoso@butantan.gov.br, ${ }^{2}$ azelanis@butantan.gov.br, ${ }^{3}$ fatifurtado@butantan.gov.br
}

\begin{abstract}
Bothrops insularis is a threatened snake endemic to Queimada Grande Island, southern coast of São Paulo, Brazil, and the occurrence of sexual abnormalities in females (females with functional ovaries and rudimentary hemipenis) has been reported in this population. To date there are few data regarding developmental features of this particular species. The aim of this study was to follow some developmental features in specimens maintained in captivity for seven years in the Herpetology Laboratory at Instituto Butantan, São Paulo, Brazil. We verified a pronounced sexual dimorphism in development and venom production in the specimens analyzed. In this regard, females showed greater length, mass and amount of venom in comparison to males. Our results suggest a possible niche partitioning between the sexes that reduces (or minimizes) intraspecific disharmonic interactions (eg. competition) on their small living area (Queimada Grande Island). Taken together, our data suggest that males and females probably are divergent in their diets, with females feeding preferentially on endothermic prey (such as migratory birds), while males maintain the juvenile diet (with the major items being ectothermic prey).
\end{abstract}

Keywords: Bothrops insularis, insular species, sexual dimorphism, venom production.

Date of publication (online): 26 September 2010 Date of publication (print): 26 September 2010 ISSN 0974-7907 (online) | 0974-7893 (print)

Editor: Aaron Bauer

Manuscript details:

Ms \# 02369

Received 22 December 2009

Final received 20 August 2010

Finally accepted 23 August 2010

Citation: Travaglia-Cardoso, S.R., A. Zelanis \& M.de.F.D. Furtado (2010). Sexual dimorphism in development and venom production of the insular threatened pit viper Bothrops insularis (Serpentes: Viperidae) of Queimada Grande Island, Brazil. Journal of Threatened Taxa 2(10): 1177-1184.

Copyright: () Silvia Regina Travaglia-Cardoso, André Zelanis \& Maria de Fátima Domingues Furtado 2010. Creative Commons Attribution 3.0 Unported License. JoTT allows unrestricted use of this article in any medium for non-profit purposes, reproduction and distribution by providing adequate credit to the authors and the source of publication.

Author Details, Author Contribution and Acknowledgement: see end of this article.

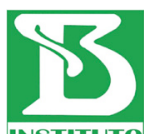

INSTITUTO

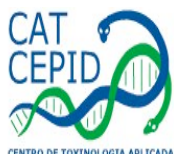

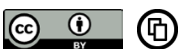

OPEN ACCESS | FREE DOWNLOAD

\section{INTRODUCTION}

Sexual dimorphism is an important morphological feature among snakes, often related to differences in ecology and behavior between males and females in many families (Shine 1994), including differences in vulnerability to predation, choice of prey items, and reproductive success (Shine 1994). Sexual dimorphism may vary in intensity during an animal's ontogeny (Beaupre et al. 1998) and may appear in neonates or only be expressed after sexual maturity (King et al. 1999). In snakes sexual dimorphism may be apparent in such characteristics as length and mass of the body (Shine 1990; Forsman 1991; Madsen \& Shine 1993; King et al. 1999; Bertona \& Chiaraviglio 2003), tail length (King et al. 1999) length and shape of the head (Shine 1990; King et al. 1999; Rodriguez-Robles 2002). These morphometric variations are usually related to sexual and ontogenetic variations in diet and may strongly influence the snake's reproductive strategies (Vanzolini 1986; Mushinsky 1987; Shine 1988; Sazima 1992; Marques et al. 2002; Shine et al. 2002; Shine 2003).

Bothrops insularis (Image 1) is a Critically Endangered snake endemic to Queimada Grande Island, southern coast of São Paulo State, Brazil (Marques et al. 2004). This species was first described by Afrânio do Amaral (Amaral 1921) as having peculiar characteristics such as a semi-arboreal habit, and both diurnal and nocturnal activity. The diet is composed of migratory birds and occasionally lizards. Chilopods are food items of juvenile snakes (Hoge et al. 1959; Martins et al. 2002). Hoge et al. (1959) showed sexual abnormalities within the $B$. insularis population, with true females, true males and intersexes all occurring. Intersexes are genetically females, with functional ovaries, but with a unilateral or bilateral non-functional hemipenis (Hoge et al. 1959). According to cytogenetic studies made by Beçak et al. (1990) this phenomenon could be due either to inbreeding or to mutations. Recently, studies concerning several aspects of the reproductive biology of $B$. insularis showed that both females and intersexes have hemipenis retractor muscles, 


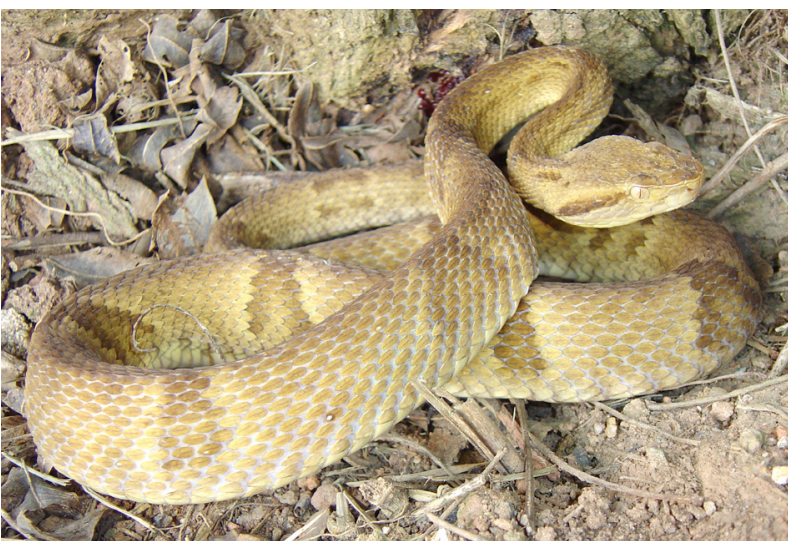

Image 1. Bothrops insularis - adult male.

and now are designated as "females" (Kasperoviczus 2009).

To date, studies on this species mainly have dealt with biological/ecolocical characteristics (Hoge et al. 1959; De Biasi et al. 1986; Federsoni et al. 1986 a,b; Duarte et al. 1995; Martins et al. 2002; Duarte \& Garrubo 2003), systematics (Salomão et al. 1999; Martins et al. 2001; Wuster et al. 2005), with few data available on reproductive strategies (Almeida-Santos \& Salomão 2002) or sexual dimorphism (Hoge et al. 1959), and none related to developmental characteristics. The lack of such data denotes the importance of studies on this species, which has been designated as Critically Endangered (CR) in the IUCN Red List of Threatened Species (Marques et al 2004). Martins et al. (2008), showed a decrease in the population size of $B$. insularis at Queimada Grande Island, a main factor reinforcing the need for conservation efforts. This work provides biological data on sexual dimorphism in the development and venom production of $B$. insularis specimens in captivity.

\section{MATERIALS AND METHODS}

\section{Study Area}

Queimada Grande Island is located approximately $34 \mathrm{~km}$ from the southern coastline of São Paulo State (24029'S \& $\left.46^{\circ} 41^{\prime} \mathrm{W}\right)$. It has been proposed that this island was isolated from the mainland about 11,000 years ago, after the last glaciation and elevation of sea level during the late Pleistocene (Vanzolini 1973). The Island is not inhabited by humans and comprises a total area of $430,000 \mathrm{~m}^{2}$, with the highest point at $200 \mathrm{~m}$. There are no sandy beaches and the vegetation is of the general Atlantic Forest pattern, with grasslands and bushy areas (Hoge 1959; Vanzolini 1973). The density of snakes is one of the highest in the world; the species represented are the endemic pit viper Bothrops insularis (Amaral 1921; Hoge et al. 1959; Duarte et al. 1995) and Dipsas albifrons cavalheiroi (Duarte et al. 1995).

\section{Snakes and their maintenance in captivity}

Gravid Bothrops insularis specimens were collected on Queimada Grande Island - SP and three clutches were obtained. Snout vent length (SVL), tail length (TL), and body mass was measured and sex determined. The animals were maintained at the Herpetology Laboratory of Instituto Butantan, São Paulo. They were placed in individual cages, in rooms with controlled temperature (24 $\pm 3^{\circ} \mathrm{C}$ ). All the animals received mice (Mus musculus) and rats (Rattus norvegicus) for food, fortnightly, until 12 months of age, and thereafter at monthly intervals. Mice of different weights were fed to the snakes, according to the snakes' length.

The small number of specimens used is because. $B$. insularis is difficult to obtain and to maintain in captivity. This Critically Endangered snake has small litter sizes (mean 6.5) (Hoge et al. 1959). Nevertheless, the results demonstrated important ontogenetic and individual shifts.

\section{Biometric data and extraction of venom}

Snout-vent length (SVL), tail length (TL) and mass were obtained over intervals of three months at which time venom was extracted from individiual snakes. All the correlation data were obtained taking into account the multiple measurements on the same animal at different ages. After extraction the venom was lyophilized and weighted.

\section{RESULTS}

\section{Biometric data and development in captivity}

Twelve animals ( 6 males and 6 females) from three litters were born in summer (February and March). Masses of the neonates varied from 7.8 to $10 \mathrm{~g}$, and SVL varied from 205 to $235 \mathrm{~mm}$. Four animals that reached adulthood and which were analyzed in this paper, were named "male", "female 1", "female 2" and "female 3". The neonates did not show significant differences of mass, SVL or TL. The analysis of the specimens that reached adulthood showed that females had higher SVL and mass than did males, although the latter had higher relative tail length. The animals showed similar patterns of growth (mass and length) up to two years of age, after which males and females diverged (Fig. 1A). Females showed an accelerated growth up to four years of age and they kept this pattern until they reached their seventh year; on the other hand; the male continued to grow up to four years of age but thereafter showed no significant changes in body size. The patterns for mass were similar, with females becoming heavier over time up to seven years but males stabilizing weight after four years of age (Fig. 1B).

Taking into account the multiple measurements on the same animal at different ages, neonates did not 

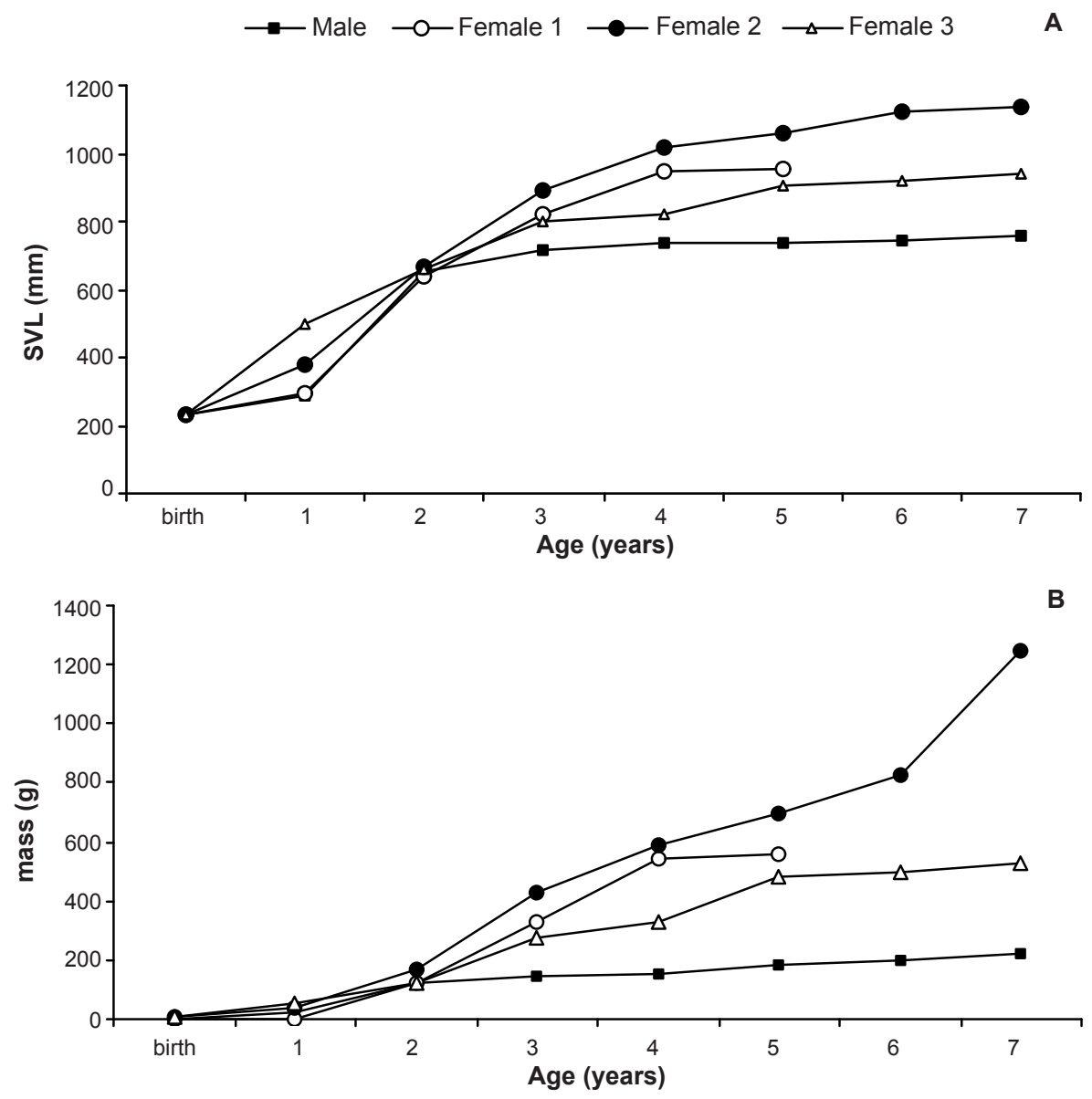

Figure 1. Growth in SVL $(\mathrm{mm})(\mathrm{A})$; and weight $(\mathrm{g})(\mathrm{B})$ of Bothrops insularis kept in captivity.

Table 1. Regression analysis of adults Bothrops insularis: biometric data and venom yield.

\begin{tabular}{|l|c|c|c|c|}
\hline & \multicolumn{2}{|c|}{ Biometric data } & \multicolumn{2}{c|}{ Venom yield } \\
\hline & SVL $(\mathbf{m m}) \mathbf{x}$ TL $(\mathbf{m m})$ & mass $(\mathbf{g}) \mathbf{x}$ total length $(\mathbf{m m})$ & venom $(\mathbf{m g}) \mathbf{x}$ total length $(\mathbf{m m})$ & venom $(\mathbf{m g}) \times \mathbf{m a s s}(\mathbf{g})$ \\
\hline Female 1 & $r^{2}=0.96$ & $r^{2}=0.85$ & $r^{2}=0.81$ & $r^{2}=0.90$ \\
\hline Female 2 & $r^{2}=0.98$ & $r^{2}=0.85$ & $r^{2}=0.71$ & $r^{2}=0.91$ \\
\hline Female 3 & $r^{2}=0.99$ & $r^{2}=0.86$ & $r^{2}=0.81$ & $r^{2}=0.90$ \\
\hline Male & $r^{2}=0.97$ & $r^{2}=0.90$ & $r^{2}=0.33$ & $r^{2}=0.43$ \\
\hline
\end{tabular}

show any correlation between TL and SVL or between TL and mass. On the other hand, among adults there was a strong correlation between TL and SVL $\left(r^{2}=0.97\right.$ for males, and $r^{2}=0.96, r^{2}=0.98$ and $r^{2}=0.99$, for females 1, 2 and 3, respectively) (Fig. 2A, Table 1). Correlation between mass and total length was found both for the male $\left(r^{2}=0.90\right)$, and for the females $\left(r^{2}=0.85 ; 0.85\right.$ and 0.86 , respectively) (Fig. 2B, Table 1 ).

Head length was not followed during animal's ontogeny, but in adults, females had larger relative length of the heads in comparison to the male (females: 3.2 to $3.8 \%$ of body length and male $3.6 \%$ of body length).

\section{Venom yield}

We verified significantly larger amounts of venom produced by females in comparison to males of the same age. Venom yield (here shown as the median per year) diverged between the sexes after two years of age, with females having a higher production of venom in comparison to the male. At the third year females' venom yield varied (73.9 to $94.3 \mathrm{mg}$ ) and the male's yield was $34.1 \mathrm{mg}$. This difference becomes increasingly significant, until at the age of seven years female 2 showed a median venom yield of $334.5 \mathrm{mg}$, while that of the male was only $51.9 \mathrm{mg}$ (Fig. 3). Taking into account the multiple measurements on the same animal at different ages, venom yield and TL were correlated in females $\left(r^{2}=0.81\right.$; 

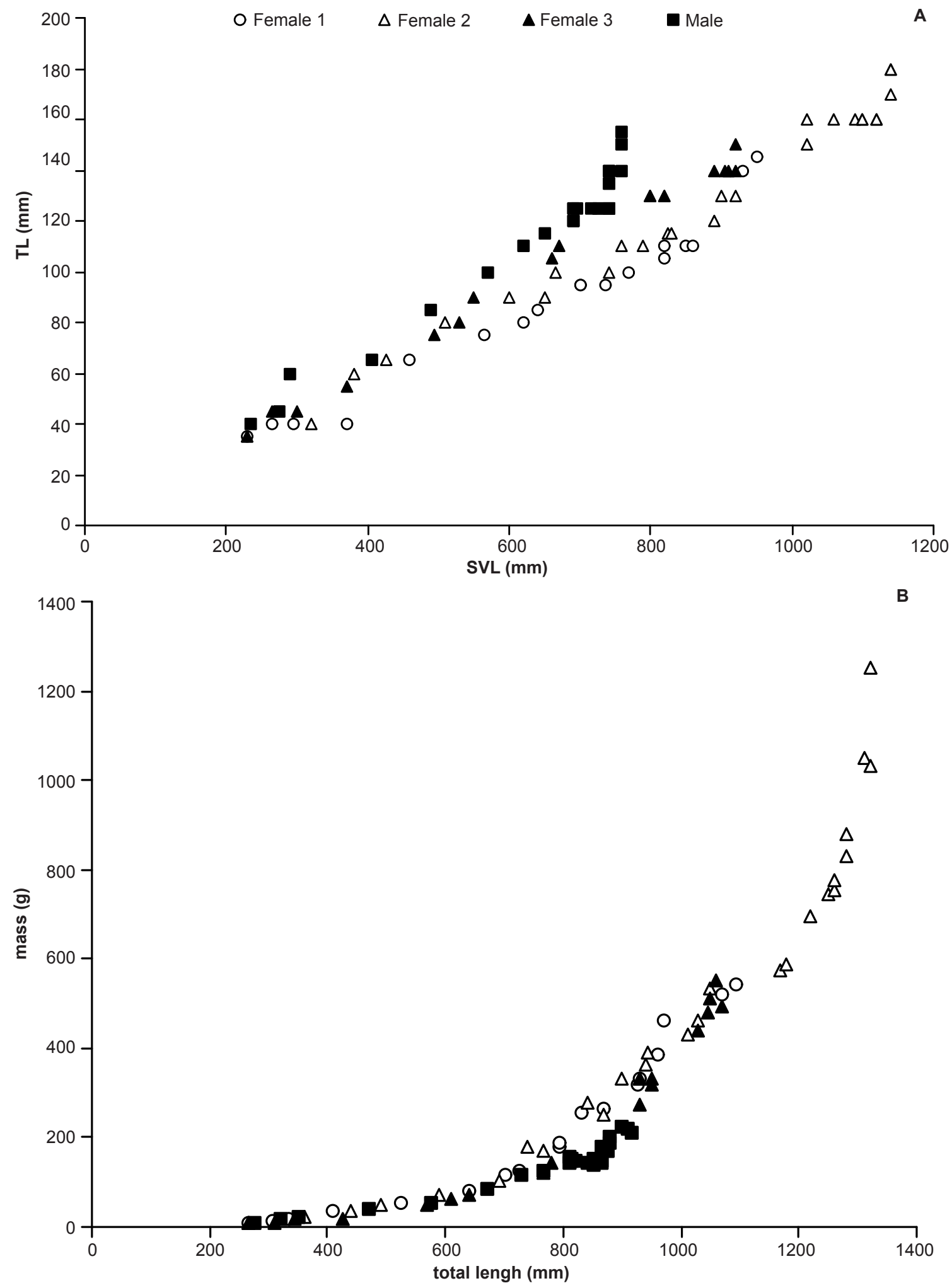

Figure 2. Tail length $(\mathrm{mm}) \times \mathrm{SVL}(\mathrm{mm})(A)$; and mass $(\mathrm{g}) \times$ total length $(\mathrm{mm})(B)$ of Bothrops insularis. 


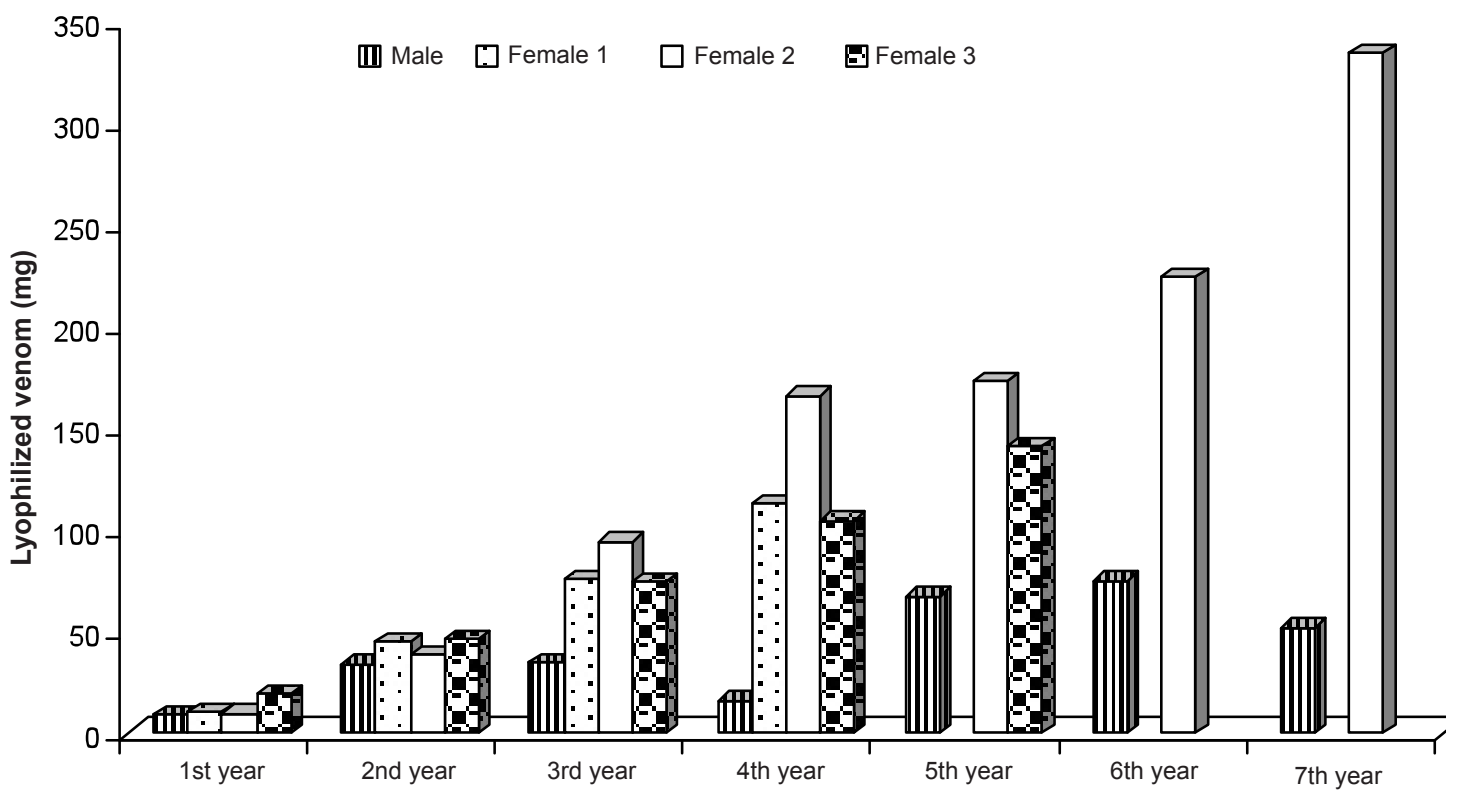

Figure 3. Bothrops insularis: venom produced (mg) (lyophilized venom) during 7 years (median per year).

$r^{2}=0.71$ and $\left.r^{2}=0.81\right)$, but only weak so in the male $\left(r^{2}=\right.$ 0.33) (Fig.4A, Table 1). The same results were found in relation to venom yield and body mass, in which a strong correlation was observed for females $\left(r^{2}=0.90 ; r^{2}=0.91\right.$ and $\left.r^{2}=0.90\right)$, and a weak one for the male $\left(r^{2}=0.43\right)$ (Fig. 4B, Table 1).

\section{DISCUSSION AND CONCLUSIONS}

There are few data for $B$. insularis, mainly in relation to its reproduction and development (Wüster 2005). We found a low clutch size and this feature is in agreement withi previous work on this species (Amaral 1921; Hoge et al., 1959; Federsoni 1987a; Wüster 2005). This species has some biological singularities that makes its maintenance in captivity a difficult task, including a small clutch size of six (Hoge et al. 1959) and its status of Critically Endangered (a major factor that restricts more wide-ranging studies). Despite these features, results obtained in this work provide an important contribution toward a better understanding of the sexual dimorphism of $B$. insularis in captivity.

Sexual dimorphism in body length is a commonlyreported feature among adult snakes; however, there are few data newborn snakes (King et al. 1999). No sexual dimorphism was observed in neonates of $B$. insularis (SVL and TL), suggesting an ontogenetic variability for this feature, since among the adults, the females were significantly larger (SVL and mass) than was the single male studied; however, the latter showed a greater tail length. These biometric features are relatively common among snakes of the genus Bothrops (Vanzolini 1991; Almeida \& Martins 1999; Furtado et al. 2006).
Differences in growth (mass and length) between the male and females were prominent, and were strongly related to attainment of sexual maturity, which in the genus Bothrops is at an age of about 24 months (AlmeidaSantos \& Salomão 2002). Fecundity is related to body length in female snakes (Seigel \& Ford 1987; Shine 1993). Females are also more robust, in keepng with the need to store fat for vitellogenesis (Shine 2003). Furthermore, the accelerated growth observed in females could also be related to greater efficacy in assimlation of food (King et al. 1999). The male had a longer tail in comparison to females, which is a common feature among snakes, likely a result of the presence of reproductive structures in the male's tail (Shine 1993; King et al. 1999).

Sexual dimorphism of the head can influence the way that an animal can feed on prey of different sizes and, in this context, prey selection may differ between males and females and/or between juveniles and adults (Forsman 1994; Vincent et al. 2004). The greater head length of females in comparison to males is a common feature among snakes (Shine 1991; King et al. 1999). While males generally feed on prey of a smaller volume (and thus potentially less dangerous), such as amphibians, lizards and, in some cases, arthropods, females usually feed on larger items, such as rodents and other small mammals (Cundall 2002; Nogueira et al. 2003). Hoge et al. (1959) and Wüster et al. (2005) have already reported sexual dimorphism in head length for $B$. insularis in which males have shorter heads in comparison to females.

Despite our lower number of specimens, our results on sexual dimorphism corroborate the findings of Hoge et al. (1959) with $B$. insularis. Venom production often shows correlations with morphological characteristics (Mackessy et al. 2003; Mackessy et al. 2006) like length, 

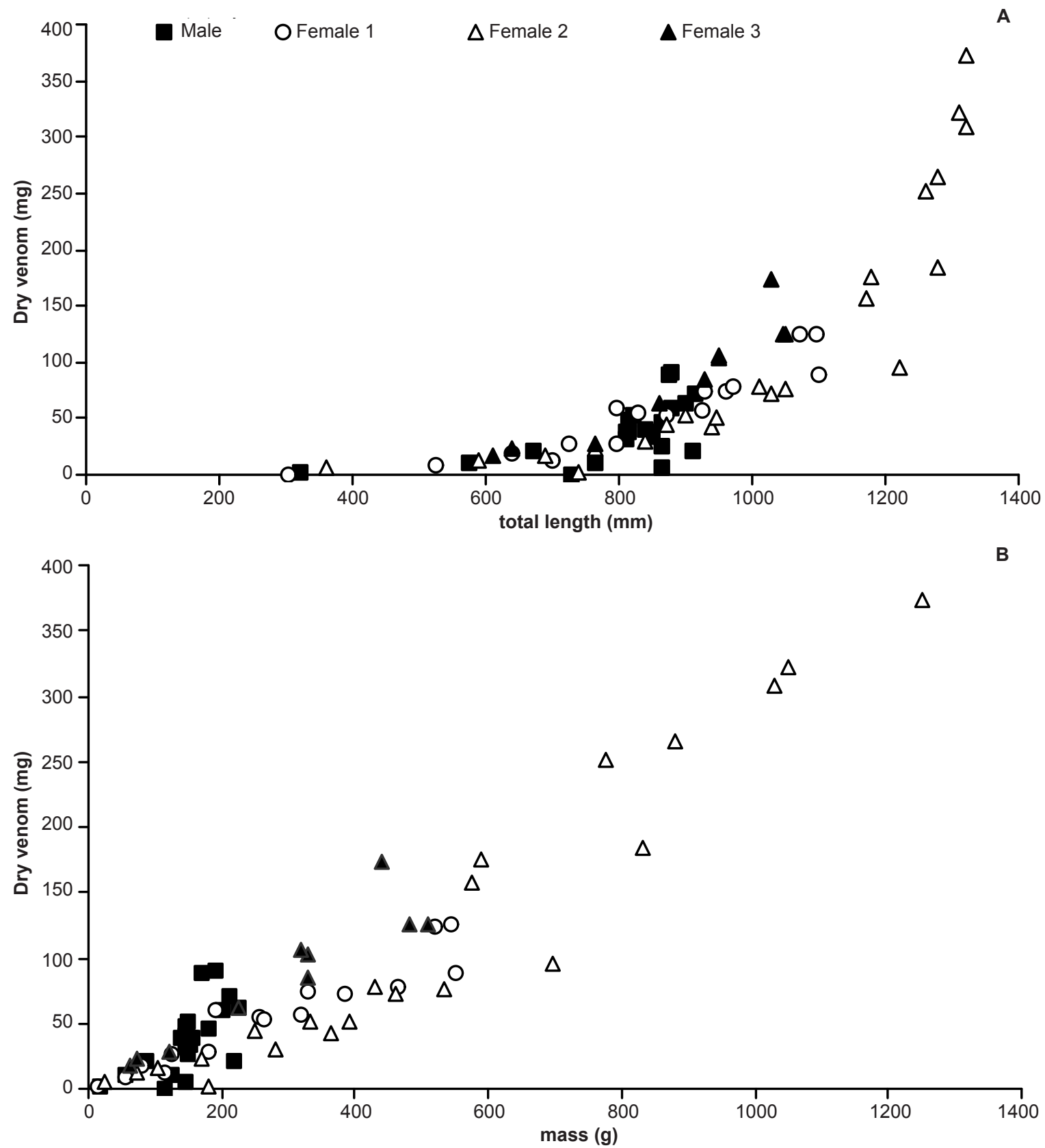

Figure 4. yields of venom produced $(\mathrm{mg}) \mathrm{x}$ total length $(\mathrm{mm})(\mathrm{A})$; and venom produced $(\mathrm{mg}) \mathrm{x}$ mass $(\mathrm{g})(\mathrm{B})$ of Bothrops insularis.

head size, and mass and usually have a tendency to increase with the snake's age. We verified an increase in venom production with age and also progressively greater divergence between the sexes with aging (mainly after 3 years). Recently Menezes et al. (2006), using proteomic analysis, showed sexual and individual variation of venom composition in $B$. jararaca, as well as important differences in the activity profile of the venom. Sexual dimorphism in the production and biological activities of venom has been found in B. jararaca (Furtado et al. 2006). Females of $B$. insularis produced more venom than the male, a feature that was also reported for $B$. jararaca, the mainland sister taxon of $B$. insularis (Furtado et al. 2006).

Moreover, Zelanis et al. (2007) showed ontogenetic changes in proteinases in the venom of $B$. insularis. Regulation of venom proteases must be a key step in a species in which diet changes ontogenetically. Being smaller and having a small amount of venom in their glands, neonates have a "problem" to face. However, ontogenetic changes in expression of venom proteins could ensure not only suitable toxins (for a specific kind of diet), but also protection against potential predators. 
Snake diets can vary according to geographic, sexual and ontogenetic factors (Shine 1990; Holycross \& Mackessy 2002). Our data suggest an increase in sexual dimorphism in B.insularis during development, and this feature could also reflect niche partitioning between the sexes that reduces (or minimizes) intraspecific disharmonic interactions (e.g. competition) on their small living area (Queimada Grande Island). Wüster et al. (2005) reported a clear difference in position of the heart between males and females (intersexes and true females): in B. insularis; in females the heart is located more anterior than in males, a feature often related to arboreality. This physiological adaptation is related to the blood supply of vital organs in the animal's head (Lillywhite 1987). In this context, it is possible that males spend more time on the ground than do females and intersexes. Taken together, these data suggest that males and females probably diverge in their diets. Females might feed preferentially on endothermic prey such as migratory birds, while males maintain a juvenile diet with the major items being ectothermic prey.

\section{REFERENCES}

Almeida-Santos, S.M. \& M.G. Salomão (2002). Reproduction in neotropical pitvipers, with emphasis on species of the genus Bothrops, pp. 445-462. In: Schuett, G.W. M. Hoggren, M.E. Douglas \& H.W. Greene (eds.). Biology of The Vipers. Eagle Mountain Publishing, Carmel, Indiana USA, 580pp.

Almeida, M.T. \& M. Martins (1999). Historia natural de Bothrops neuwiedi pubescens (Serpentes, Viperidae). Abstracts of the 5th Congress of Herpetology of Latin American - Uruguay, 26pp.

Amaral, A. (1921). Contribuição para o conhecimento dos ofídeos do Brasil. A Parte I. Biologia de uma nova espécie, Lachesis insularis. Anexos Memória do Instituto Butantan 1 (1): 18-37.

Beaupre, S.J., D. Duvall \& J. O’Leile (1998). Ontogenetic variation in growth and sexual size dimorphism in a Central Arizona population of the Western Diamondback Rattlesnake (Crotalus atrox). Copeia 1998: 40-47.

Beçak, M.L., M.N. Rabello-Gay, W. Beçak, M. Soma, R.F. Batistic \& I. Trajtengertz (1990). The W chromossome during the evolution and in sex abnormalities of snakes. DNA content, C-banding, pp. 221-240. In: Olmo, E. (ed). Cytogenetics of Amphibians and Reptiles. Birkhauser Verlag, Basel.

Bertona, M. \& M. Chiaraviglio (2003). Reproductive biology, mating aggregations, and sexual dimorphism of the argentine Boa constrictor (Boa constrictor occidentalis). Journal of Herpetology 37(3): 510-516.

Cundal, D. (2002). Envenomation strategies, head form, and feeding ecology in vipers, pp. 149-161. In: Schuett, G.W. M. Hoggren, M.E. Douglas \& H.W. Greene (eds.). Biology of The Vipers. Eagle Mountain Publishing, Carmel, Indiana USA, 580pp.

De Biasi, P., P.A. Federsoni Jr, M.A. Buononato \& G. Puorto (1986). Comportamento de Bothrops insularis (Amaral) Ilha da Queimada Grande - São Paulo - Brasil (SerpentesViperidae-Crotalinae). Resumos do XIII Congresso Brasileiro de Zoologia - Cuiabá-MT.

Duarte, M.R. \& P.S. Garrubo (2003). Bothrops insularis (Golden Lancehead). Diet. Herpetological Review 34(2): 148.
Duarte, M.R., G. Puorto \& F.L. Franco (1995). A biological survey of the pitviper Bothrops insularis Amaral (Serpentes, Viperidae): an endemic and threatened offshore island snake of southeastern Brazil. Studies on Neotropical Fauna and Environment 30(1): 1-13.

Federsoni Jr, P.A., M.A. Buonoato, N. Vitiello \& E. Zolcsak (1986a). Observações sobre alimentação de ninhadas de Bothrops insularis, no biotério do Museu do Instituto Butantan (Serpentes-Viperidae-Crotalinae). Resumos do XIII Congresso Brasileiro de Zoologia - Cuiabá-MT: 138.

Federsoni Jr, P.A., M.A. Buonoato, G. Puorto \& P. De Biasi (1986b). Exame de conteúdo estomacal de um jovem (Serpentes-Viperidae-Crotalinae). Resumos do XIII Congresso Brasileiro de Zoologia - Cuiabá-MT: 138.

Forsman, A. (1991). Variation in sexual size dimorphism and maximum body size among adder populations: effects of prey size. Journal of Animal Ecology 60: 253-267.

Forsman, A. (1994). Growth rate and survival in relation to relative head size in Vipera berus.Journal of Herpetology 28(2): 231-238.

Furtado, M.F.D., S.R.T. Travaglia-Cardoso \& M.M.T. Rocha (2006). Sexual dimorphism in venom of Bothrops jararaca (Serpentes: Viperidae). Toxicon 48: 401-410.

Hoge, A.R., H.E. Belluomini, G. Schreiber \& A.M. Penha (1959). Sexual abnormalities in Bothrops insularis (Amaral) 1921 (Serpentes). Mem.Inst. Butantan 29: 17-88.

Holycross, A.T. \& S.P. Mackessy (2002). Variation in the diet of Sistrurus catenatus (Massasauga), with emphasis on Sistrurus catenatus edwardsii (Desert Massasauga). Journal of Herpetology 36(3): 454-464.

Kasperoviczus, K.N. (2009). Biologia reprodutiva da jararaca ilhoa, Bothrops insularis (Serpentes:Viperidae) da Ilha da Queimada Grande, São Paulo. Msc Thesis. Biotechnology and Biodiversity Program (USP/Butantan Institute/IPT), São Paulo University, 124pp.

King, R.B., T.D. Bittner, A. Queral-Regil \& J.H. Cline (1999). Sexual dimorphism in neonate and adult snakes. Journal Zool. London 247: 19-28.

Lillywhite, H.B. (1987). Circulatory adaptations of snakes to gravity. Animal Zoology 27: 81-95.

Martins, M., O.A.V. Marques \& I. Sazima (2002). Ecological and phylogenetic correlates of feeding habits in neotropical pitvipers of the genus Bothrops, pp. 307-328. In: Schuett, G.W. M. Hoggren, M.E. Douglas \& H.W. Greene (eds.). Biology of The Vipers. Eagle Mountain Publishing, Carmel, Indiana USA, 580pp.

Martins, M., R.J. Sawaya, O.A.V. Marques (2008). A first estimate of the population of the critically endangered lancehead, Bothrops insularis. South American Journal Herpetology 3: 168-174.

Mackessy, S.P., K. Williams \& K.G. Ashton (2003). Ontogenetic variation in venom composition and diet of Crotalus oreganos concolor. A case of venom paedomorphosis? Copeia 2003: 769-782.

Mackessy, S.P., N.M. Sixberry, W.H. Heyborne \& T. Fritts (2006). Venom of the brown treesnake, Boiga irregularis: ontogenetic shifts and taxa-specific toxicity. Toxicon 47: 537548.

Madsen, T. \& R. Shine (1993). Phenotipic plasticity in body sizes and sexual dimorphism in european grass snakes. Evolution 46(1): 321-325.

Marques O.A.V., M. Martins \& I. Sazima (2002). A new insular species of pitviper from Brazil, with comments on evolutionary biology and conservation of the Bothrops jararaca group (Serpentes:Viperidae). Herpetologica 58: 303-312.

Marques O.A.V., M. Martins \& I. Sazima (2004). Bothrops insularis, IUCN 2004. 2004 IUCN Red List of Threatened Species. <www.iucnredlist.org $>$. Downloaded on 23 September 2010. 
Martins, M., M.S. Araujo, R.J. Sawaia \& R. Nunes (2001). Diversity and evolution of macrohabitat use, body size and morphology in a monophyletic group of Neotropical pitvipers (Bothrops). Journal of Zoology, London 254: 529-538.

Menezes, M.C., M.F.D. Furtado, S.R. Travaglia-Cardoso, A.C.M. Camargo \& S.M.T. Serrano (2006). Sex-based individual variation of snake venom proteome among eighteen Bothrops jararaca siblings. Toxicon 47: 304-312.

Mushinsky, H.R. (1987). Foraging Ecology, pp. 302-334. In: Seigel, R.A., J.T. Collins \& S.S. Novak (eds.). Snakes: Ecology and Evolutionary Biology. MacMillan Publishing Company, New York, 529pp.

Nogueira, C., R.J. Sawaya \& M. Martins (2003). Ecology of the Pitviper, Bothrops moojeni, in the Brazilian Cerrado. Journal of Herpetology 37: 653-659.

Rodriguez-Robles, J.A. (2002). Feeding ecology of North American gopher snakes (Pituophis catenifer, Colubridae). Biological Journal of the Linnean Society 77: 165183.

Salomão, M.G., W. Wüster \& R.S. Thorpe (1999). MtDNA Phylogeny of neotropical pitvipers of the genus Bothrops (Squamata: Serpentes: Viperidae). Kaupia 8:127-134.

Sazima, I. (1992). Natural history of the jararaca pitviper, Bothrops jararaca, in southeastern Brazil, pp. 199-216. In: Campbell, J.A. \& E.D. Brodie (eds.). Biology of the Pitvipers. Selva Publishing, Tyler, Texas,USA, 467pp.

Seigel, R.A. \& N.B. Ford (1987). Reproductive ecology, pp. 210-252. In: Seigel, R.A., J.T. Collins \& S.S. Novak (eds.). Snakes: Ecology and Evolutionary Biology. MacMillan Publishing Company, New York, 529pp.

Shine, R. (1988). Constraints on reproductive investment: a comparison between aquatic and terrestrial snakes. Evolution 42: 17-27.

Shine, R. (1990). Proximate determination of sexual differences in adult body size. American Naturalist 135(2): 278-283.

Shine, R. (1991). Intersexual dietary divergence and the evolution of sexual dimorphism in snakes. American Naturalist 138: 103-122.

Shine, R. (1993). Sexual dimorphism in snakes, pp. 49-86. In: Seigel, R.A. \& J.T. Collins (eds.). Snakes: Ecology \& Behavior. McGraw-Hill, New York, USA, 414pp.

Shine, R. (1994). Sexual size dimorphism in snakes revisited. Copeia 1994: 326-346.

Shine, R. (2003). Reproductive strategies in snakes. Proceedings of the Royal Society of London, Series B. 270: 995-1004.

Shine, R., L. Sun, M. Kearney \& M. Fitzgerald (2002). Why do juvenile chinese pit-vipers (Gloydius shedaoensis) select arboreal ambush sites?. Ethology 108: 897-910.

Vanzolini, P.E. (1973). Distribution and differentiation of animals along the coast and continental island of the state of São Paulo, Brasil I. Introduction to the area and problems. Papéis Avulsos de Zoologia 16: 281-294.

Vanzolini, P.E. (1986). Levantamento herpetológico da área do Estado de Rondônia sob a influência da rodovia BR 364. Polonoroeste. Ecologia Animal. DF, Rel. Pesq. 1, CNPQ, 50pp.

Vanzolini, P.E. (1991). A biometrical note on Bothrops moojeni Hoge, 1966 (Serpentes:Viperidae). Anais Academia Brasileira de Ciências 63(4): 389- 401.

Vincent, S.E., A. Herrel \& D.J. Irschick (2004). Ontogeny of intersexual head shape and prey selection in the pitviper Agkistrodon piscivorus. Biological Journal of the Linnean Society 81: 151-159.

Wüster, W., M.R. Duarte \& M.G. Salomão (2005). Morphological correlates of incipient arboreality and ornithophagy in island pitvipers, and the phylogenetic position of Bothrops insularis. Journal of Zoology, London 266: 1-10.

Zelanis, A., J.S. Ventura, A.M. Chudzinski-Tavassi \& M.F.D. Furtado (2007). Variability in expression of Bothrops insularis snake venom proteases: An ontogenetic approach. Comparative Biochemistry and Physiology 145: 601-609.
Author Details: SILVIA R. TRAVAgliA-CARDoso is a researcher from the Herpetology Laboratory, at Butantan Institute, São Paulo, Brazil. She is currently a PhD student in USP. Her main research field is the reproduction and maintenance of snakes in captivity.

AndRÉ Zelanis is a PhD student at Center for Applied Toxinology (CAT/CEPID) at Butantan Institute, São Paulo, Brazil. His main research field is the variability found in the venom proteome of South American snakes.

Maria de Fátima Domingues Furtado is a researcher from the Herpetology Laboratory, at Butantan Institute, São Paulo, Brazil. She has performed her PhD in Physiology at Biosciences Institute at São Paulo University. Her main research is the venoms of snakes and the biological variability.

Author Contribution: SRTC - maintaining the snakes in captivity, biometrical data measurement, venom extraction, discussion of the results and writing the paper. AZ biometrical data measurement, discussion of the results and writing the paper. MdeFDF - experimental design, discussion of the results and writing the paper.

Acknowledgement: Fundação de Amparo à Pesquisa do Estado de São Paulo FAPESP (grant \# 06/60486-0). 